\title{
In situ net primary productivity of an Antarctic fast ice bottom algal community
}

\author{
Andrew McMinn ${ }^{1 *}$ Chris Ashworth ${ }^{2}$, Ken G. Ryan ${ }^{3}$ \\ ${ }^{1}$ Institute of Antarctic and Southern Ocean Studies, University of Tasmania, Box 252-77, Hobart 7001, Tasmania, Australia \\ ${ }^{2}$ Dept of Plant Science, University of Tasmania, Box 252-55, Hobart 7001, Tasmania, Australia \\ ${ }^{3}$ Industrial Research Ltd, Gracefield Rd, Lower Hutt, Wellington, New Zealand
}

\begin{abstract}
Net primary production was measured in situ in an Antarctic fast ice bottom algal mat at Cape Evans, McMurdo Sound, Antarctica. Under-ice PAR irradiances between 18 November and 4 December 1997 were between 3 and $55 \mu \mathrm{mol}$ photons $\mathrm{m}^{-2} \mathrm{~s}^{-1}$. This produced a net oxygen export between 0.0084 and $0.0440 \mathrm{nmol} \mathrm{O}_{2} \mathrm{~cm}^{-2} \mathrm{~s}^{-1}$. $P_{\max }$ was $0.034 \mathrm{nmol} \mathrm{O} \mathrm{cm}^{-2} \mathrm{~s}^{-1}, E_{\mathrm{k}}$ was $14 \mu \mathrm{mol}$ photons $\mathrm{m}^{-2} \mathrm{~s}^{-1}$ and the compensation point was approximately $2 \mu \mathrm{mol}$ photons $\mathrm{m}^{-2} \mathrm{~s}^{-1}$. These values are equivalent to a carbon-based production of 3.50 to $18.46 \mathrm{mg} \mathrm{C} \mathrm{m}^{-2} \mathrm{~h}^{-1}$ and assimilation numbers of between 0.294 and $2.01 \mathrm{mg} \mathrm{C} \mathrm{mg}^{-1} \mathrm{chl} \mathrm{a} \mathrm{h}^{-1}$. Production levels on sunny days were so high that oxygen bubbles formed at the ice water interface and presumably contributed to the demise of the algal mat. Grazing by amphipods was also observed. While increasing net oxygen export was found to be strongly correlated with increasing irradiance, increasing under-ice current velocity was also found to increase production. The reduction in diffusive boundary layer thickness caused by increasing current velocity would have allowed both a more efficient transport of nutrients into the mat and a more efficient transport of oxygen away from the mat. Accumulation of sea ice algal biomass is not just a function of light but is also influenced by under-ice current velocity and possibly by oxygen build-up and grazing by amphipods and other invertebrates. In spite of the high under-ice irradiances reported from Cape Evans, loss mechanisms such as grazing and possibly oxygen toxicity were able to prevent the buildup of additional biomass.
\end{abstract}

KEY WORDS: Antarctica - Sea ice - Diatoms - Primary production

\section{INTRODUCTION}

Each year sea ice expands to cover over 20 million $\mathrm{km}^{2}$ of the Southern Ocean and 8 million $\mathrm{km}^{2}$ of the Arctic Ocean (Maykut 1985, Legendre et al. 1992). This ice severely reduces the amount of light available for phytoplankton production but provides a stable habitat for sea ice algal colonisation and growth. Sea ice algae, while extremely shade adapted, still contribute at least $20 \%$ of the primary productivity of perennially ice-covered areas (Legendre et al. 1992). Biomass in the fast ice (i.e. annual ice attached to shore) can exceed $300 \mathrm{mg}$ chlorophyll a (chl a) $\mathrm{m}^{-2}$ (Palmisano \& Sullivan 1983) and a biomass between 90 and $120 \mathrm{mg}$ chl $a \mathrm{~m}^{-2}$ is common (Smith et al. 1989, McMinn \& Ashworth 1998).

\footnotetext{
•E-mail: andrew.mcminn@utas.edu.au
}

Light has usually been considered the main limitation to photosynthesis in fast ice bottom communities (Palmisano et al. 1985, Smith et al. 1988, Cota \& Smith 1991) and there is considerable evidence for extreme shade adaptation (Palmisano et al. 1985, 1987, Irwin 1990, Lizotte \& Sullivan 1991). There is now also evidence that nutrients (Maestrini et al. 1986, Palmisano et al. 1988, Lizotte \& Sullivan 1992, McMinn et al. 1999a) and even ultraviolet-B radiation (Ryan \& Beaglehole 1994, McMinn et al. 1999b) might reduce, and perhaps even limit, production in some circumstances.

Determining productivity in sea ice algal communities, both from the Arctic as well as the Antarctic, has always been problematic. Most studies have used the ${ }^{14} \mathrm{C}$ method to measure productivity (Steemann Nielsen 1952). Ice samples from the bottom of the sea ice were melted in filtered sea water to extract the algae and these concentrates were then resuspended in bottles and placed either under the ice or in an incubator to deter- 
mine the photosynthetic rate under ambient or a range of irradiances (McConville \& Wetherbee 1983, Palmisano \& Sullivan 1983, Cota \& Horne 1989, Lizotte \& Sullivan 1992). In sea ice algal mats, however, cells closest to the top of the ice experience irradiances considerably higher and of different spectral properties than those at the bottom (SooHoo et al. 1987, Palmisano et al. 1988, McMinn et al. 1999b). The irradiance selected for illumination has usually been that measured beneath the ice and thus that experienced by only the lowest positioned algal cells. This method thus fails to accommodate the effects of self shading, nutrient limitation and diffusion barriers on productivity that occur within algal mats. This problem was partly overcome by McMinn \& Ashworth (1998), who worked on the productivity of sea ice cores using the fiux of oxygen across the diffusive boundary layer method (Jørgensen \& Revsbech 1985, Jørgensen \& Des Marais 1990), but even this approach modified the natural conditions by inverting the ice core and using artificial illumination. Here, we describe how we obtained in situ net sea ice algal productivity estimates by measuring the oxygen flux across the diffusive boundary layers with micro oxygen electrodes located beneath the sea ice. In these measurements the sea ice algal communities are not handled at all, the illumination is completely natural and the algal mats are exposed to the full range of natural processes that have the potential to effect productivity such as nutrient limitation, current strength and grazing.

\section{MATERIALS AND METHODS}

Field work was carried out at a site on the sea ice 200 m north of Cape Evans, McMurdo Sound, between 18 November and 4 December 1997 (Fig. 1). The weather during this period was mostly overcast and windy although cloud-free conditions were experienced occasionally. Temperature measurements were made with a WTW conductivity meter through a $25 \mathrm{~cm}$ Jiffy drill hole beneath the ice.

The in situ under-ice deployment and measuring equipment was designed and constructed to measure the oxygen flux across the diffusive boundary layer (DBL) at the ice water interface (Fig. 2). A $25 \mathrm{~cm}$ diameter Jiffy drill hole through the sea ice was used to deploy the equipment. The equipment was composed of an articulated arm attached to an underwater micromanipulator, which deployed a probe assembly $2 \mathrm{~m}$ away from the local effects of the hole in the ice. This was the distance thought necessary to minimize light interference from the hole (Buckley \& Trodahl 1990, Ryan \& Beaglehole 1994). The probe assembly consisted of a small video camera, a micro oxygen electrode and an optical fiber light probe which was posi-

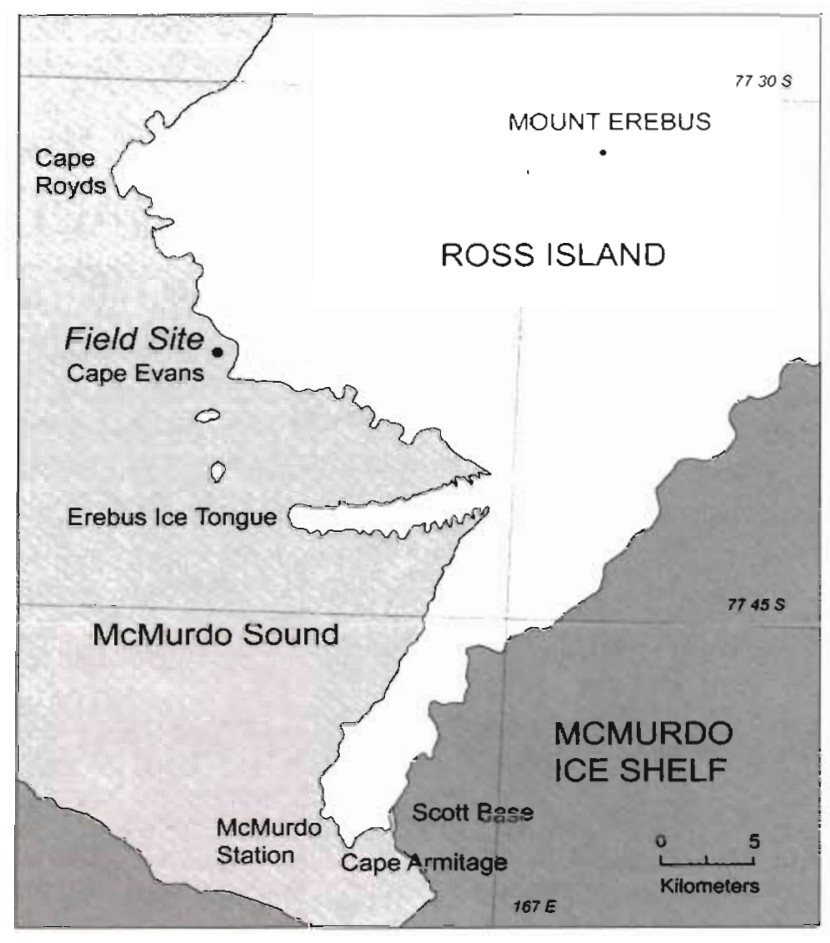

Fig. 1. Location of field site at Cape Evans, McMurdo Sound

tioned vertically by a computer at the surface. The light sensor was located approximately $2 \mathrm{~cm}$ horizontally from the oxygen electrode and set back approximately $200 \mu \mathrm{m}$ below the electrode tip. The equipment was purpose built as a self-contained, hydraulically operated unit at the University of Tasmania

Oxygen concentration was measured with purposebuilt PME (Precision Measurement Engineering, Encinitras) micro oxygen electrodes. These had a tip diameter of approximately $40 \mu \mathrm{m}$, a $90 \%$ response time of approximately $1 \mathrm{~s}$ and a stirring effect of between 1 and $2 \%$. They were calibrated on site by obtaining values for air-saturated seawater (saturated by bubbling with a standard aquarium pump for 20 min) and for deoxygenated seawater (deoxygenated with sodium nitrite). Oxygen concentration values, in $\mu \mathrm{mol} 1^{-1}$, for air saturated seawater at $-1.88^{\circ} \mathrm{C}$ were obtained from Weiss (1970). Fiber optic light probes were constructed after Kuhl et al. (1994) and calibrated with a Biospherical QSP $2004 \pi$ PAR sensor. All light measurements were made beneath the mat. A Biospherical QSP 200 $2 \pi$ sensor was used to measure surface irradiance. The custom-built, $40 \mathrm{~mm}$ diameter, probe tip camera was comprised of a MOD-BW202 pcb mini board video camera with a $5.5 \mathrm{~mm}$ F3.8 pin hole lens imaging onto a $1 / 3$ inch CCD. Composite video was transmitted to the surface control unit, which also provided power to the camera via a 75 ohm coaxial cable. The lens focus was adjusted to image the electrode tip. 
Oxygen flux measurements, which were recorded once a second, were made by stepping the probes through the DBL at $10 \mu \mathrm{m}$ intervals. Recognition of the bottom of the DBL was by repeated $\mathrm{O}_{2}$ values or a fall in $\mathrm{O}_{2}$ concentration associated with touching the ice. It could also be observed with reasonable clarity on a video monitor. The top of the DBL was calculated by determining the depth at which there had been an increase of $10 \%$ of the total change in oxygen concentration (i.e. the oxygen export equivalent of the $90 \%$ of 'free-flow concentration' of Jørgensen \& Des Marais 1990). All data were logged directly onto a PC. Underwater video cameras were positioned $5 \mathrm{~m}$ from the measuring equipment and approximately $10 \mathrm{~cm}$ from the electrode tip. The former was to ensure that the equipment was correctly positioned and the latter to observe the electrode tip entering the mat.

Whenever possible oxygen profiles were measured over the same spot to ensure that biomass was unvarying. However, in practice the electrodes had to be moved regularly to avoid or remove fouling by dangling strands of algae and to replace the fragile electrodes, which were easily damaged, or to avoid oxygen bubbles. They were occasionally also moved by strong currents. The measured $\mathrm{O}_{2}$ gradients over the $\mathrm{DBL}$ were used to calculate the net oxygen production in light. The oxygen diffusion flux $(J)$ across the DBL is equivalent to the net productivity of the algal mat and was calculated using the 1-dimensional version of Fick's first law of diffusion (Revsbech \& Jørgensen 1986):

$$
J=\mathrm{d}\left[\mathrm{O}_{2}\right] / \mathrm{d} \mathrm{x} \times D_{0}
$$

where $D_{0}=$ molecular diffusion coefficient (at $-1.9^{\circ} \mathrm{C}=$ $1.11 \times 10^{-5} \mathrm{~cm}^{2} \mathrm{~s}^{-1}$ (Broecker \& Peng 1974), $\mathrm{dx}=$ effective DBL thickness (Jørgensen \& Revsbech 1985) or $90 \%$ level (Jørgensen \& Des Marais 1990), d $\left[\mathrm{O}_{2}\right]=$ change in oxygen concentration across the DBL. The photosynthetic quotient was assumed to be 1.03 (Satoh \& Watanabe 1988).

Five replicate samples for chlorophyll analysis were taken from within $1 \mathrm{~m}$ of the productivity measurement site with a $7.5 \mathrm{~cm}$ diameter SIPRE corer at the beginning and end of the productivity measurements. The bottom $20 \mathrm{~cm}$ of each ice core was melted into filtered sea water and concentrated onto GF/F filters. These were then frozen for later analysis at the University of Tasmania. Analysis was with a Shimatzu UV1201 spectrophotometer following the methods of Strickland \& Parsons (1972). Errors represent standard deviations. Algal species from the melted ice samples were identified on a Zeiss S20 microscope using a 100x phase contrast, oil immersion objective.

The photosynthetic parameters $P_{\max }$ (maximum photosynthetic rate), $E_{k}$ (irradiance of the onset of saturation)) were obtained with a nonlinear regression of the production data against a hyperbolic tangent function (Jassby \& Platt 1976); i.e.

$$
P=P_{\max } \tanh \left(\alpha \times E / P_{\max }\right)-I
$$

where $\tanh \left(\alpha \times E / P_{\max }\right)=\left(\mathrm{e}^{\left(2 E \alpha / P_{\max }\right)}-1\right) /\left(\mathrm{e}^{\left(2 E \alpha / P_{\operatorname{mux}}\right)}+1\right)$ This derivation of $\tanh (x)$ follows Dwight (1961). $P=$ productivity, $P_{\max }=$ maximum photosynthetic rate, $E=$ irradiance, $\alpha=$ photosynthetic efficiency and $r=$ respiration constant.

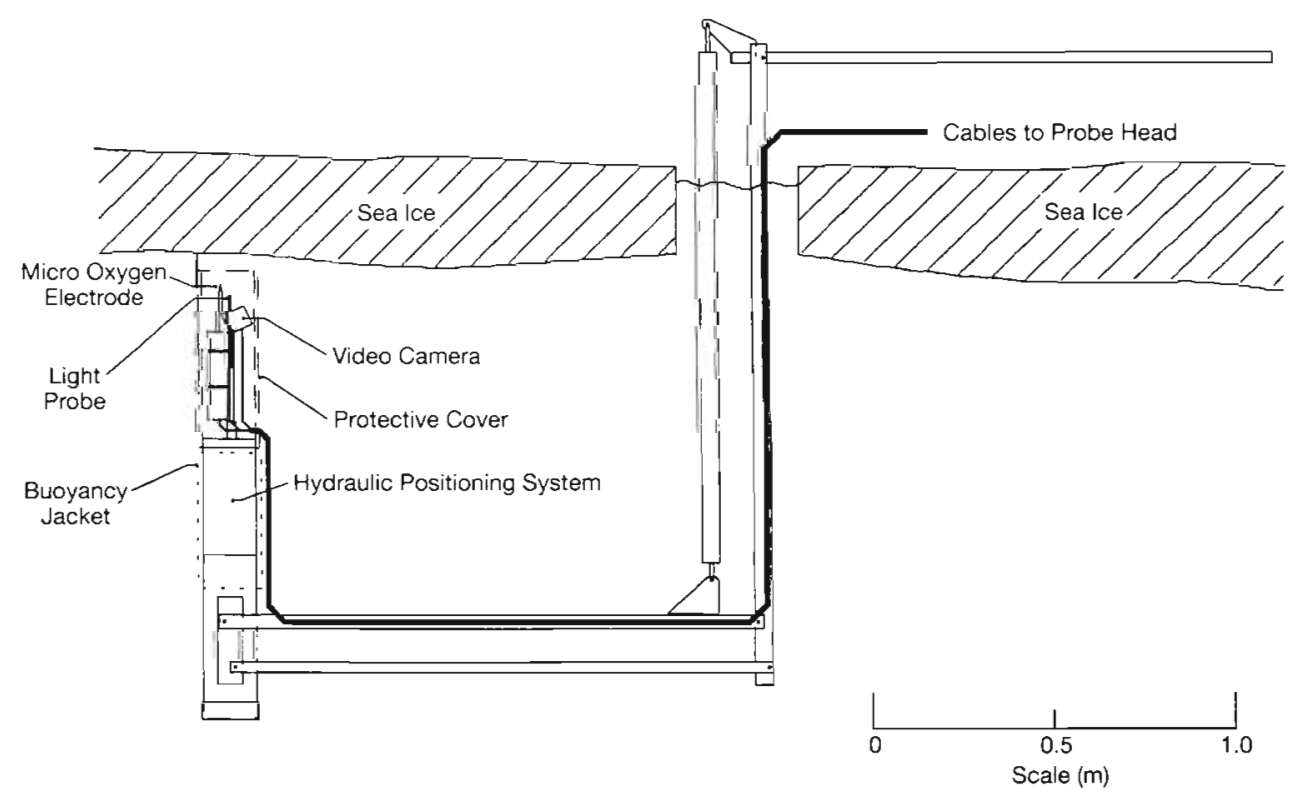

Fig. 2. Design of in situ under-ice productivity measuring equipment 
A term for photoinhibition (Platt et al. 1980) was not added to the equation, as the community showed no evidence of photoinhibition at the highest irradiances measured (following Dodds et al. 1999). The addition of the term also led to poorer solutions to the nonlinear regression.

The nonlinear regression estimates the values of $P_{\max }, \alpha$ and r. $E_{k}$ is calculated by dividing $P_{\max }$ by $\alpha$. Systat was used for a stepwise multiple regression on the productivity, irradiance and DBL thickness data.

A rough estimate of current strength was made by timing the movement of particles in front of the video camera. Amphipod numbers were also estimated from underwater video images.

\section{RESULTS}

Between 26 and 30 November the water column down to $30 \mathrm{~m}$ was well mixed with a temperature between $-1.7^{\circ}$ and $-1.8^{\circ} \mathrm{C}$. Oxygen profiles were obtained each day between 26 and 30 November, although only 1 successful profile was obtained on 26 November and 3 on 28 November. Midday surface irradiances were up to $1600 \mu \mathrm{mol}$ photons $\mathrm{m}^{-2} \mathrm{~s}^{-1}$, although this was often reduced by cloud cover. Under-ice irradiances were up to $55 \mu \mathrm{mol}$ photons $\mathrm{m}^{-2} \mathrm{~s}^{-1}$ during cloud-free conditions and ranged down to $3 \mu \mathrm{mol}$ photons $\mathrm{m}^{-2} \mathrm{~s}^{-1}$ around midnight. The ice was $90 \mathrm{~cm}$ thick and snow-free throughout the study period.

The ice algal mat was strongly dominated by the diatom Nitzschia stellata (94\% of algal cells) with
Berkelaya adeliense, Pleurosigma antarctica and Nitzschia lecoitei also present. Chl a biomass was 17.1 $\pm 1.9 \mathrm{mg} \mathrm{chl} \mathrm{a} \mathrm{m}^{-2}$ on 20 November but had decreased to $9.2 \pm 3.2 \mathrm{mg} \mathrm{chl} \mathrm{a} \mathrm{m} \mathrm{m}^{-2}$ by 1 December. However a Student's $t$-test showed that the difference between these 2 means was not significant at $p<0.05$. The Mann-Whitney $U$-test (nonparametric) confirmed this result. Chl a biomass at nearby snow-covered sites averaged only $0.91 \pm 0.19 \mathrm{mg}$ chl $a \mathrm{~m}^{-2}$ and the algal mat assemblage there was dominated by $N$. stellata (55\% of algal cells) but with higher proportions of Entomeneis kjellmannii (15\% of algal cells), B. adeliense $(10 \%$ of algal cells) and $P$. antarctica (4\% of algal cells) than at the snow-free sea ice site. E. kjellmannii and $N$. stellata typically dominate interstitial sea ice communities (NícConvilie \& Wetherbee 1983. McMinn 1998), while $B$. adeliense forms under ice hanging communities (Watanabe 1988, McMinn 1998).

Although oxygen profiles could be measured as often as every $5 \mathrm{~min}$, in practice this was only rarely done. However, many measurements were made over a wide range of irradiances and current strengths. Examples of measurements taken over $2 \mathrm{~d}$ are given in Fig. 3, which illustrates the relationship between productivity and irradiance during part of a day. All of the data obtained over the period 26 to 30 November are summarized on a $P$ versus $E$ curve in Fig. 4. Net oxygen export increased from $0.0084 \mathrm{nmol} \mathrm{O} \mathrm{Cm}^{-2} \mathrm{~s}^{-1}$ at irradiances around $3 \mathrm{\mu mol}$ photons $\mathrm{m}^{-2} \mathrm{~s}^{-1}$ to over $0.044 \mathrm{nmol} \mathrm{O}_{2} \mathrm{~cm}^{-2} \mathrm{~s}^{-1}$ at irradiances of over $50 \mu \mathrm{mol}$ photons $\mathrm{m}^{-2} \mathrm{~s}^{-1}$. Assuming a photosynthetic quotient of 1.03 for fast ice algal communities (Satoh \& Watanabe
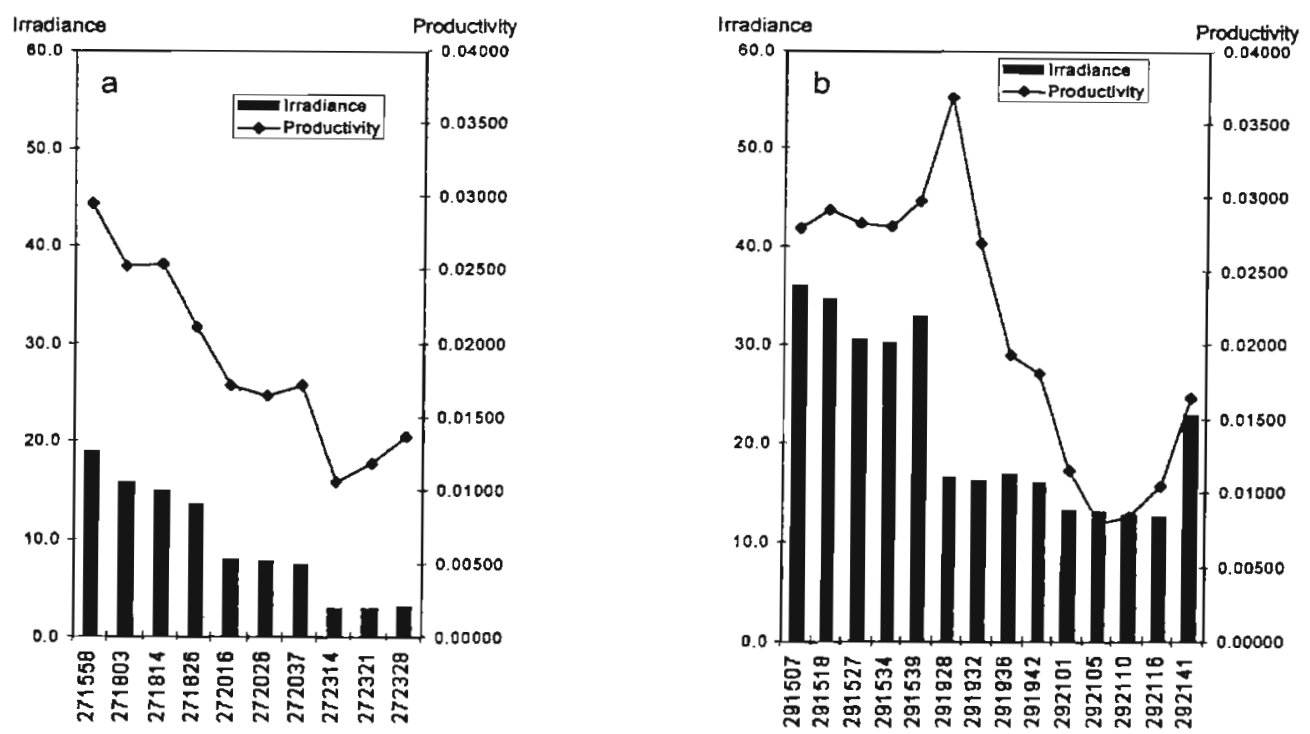

Fig. 3. Change in productivity ( $\left.\mathrm{nmol} \mathrm{O}_{2} \mathrm{~m}^{-2} \mathrm{~h}^{-1}\right)$ with irradiance ( $\mu \mathrm{mol}$ photons $\left.\mathrm{m}^{-2} \mathrm{~s}^{-1}\right)$ and time of day. Time of day is on the $x$-axis (date, hour, minute), production is represented by the solid bars (scale on the right $y$-axis), and irradiance by the solid line ( $\mu \mathrm{mol}$ photons $\mathrm{m}^{-2} \mathrm{~s}^{-1}$ ) with the scale on the left $y$-axis. (a) Data from 27 November, (b) data from 29 November 
1988), this is equivalent to a carbon-based productivity range of 3.50 to $18.46 \mathrm{mg} \mathrm{C} \mathrm{m}^{-2} \mathrm{~h}^{-1}$ and assimilation numbers between 0.294 and $2.01 \mathrm{mg} \mathrm{C} \mathrm{mg}^{-1} \mathrm{chl} a$. These data, when fitted to a hyperbolic tangent function (Jassby \& Platt 1976), produce a value for the $P_{\max }$ of $0.034 \mathrm{nmol} \mathrm{O}_{2} \mathrm{~cm}^{-2} \mathrm{~s}^{-1}$, an $E_{k}$ of $14 \mu \mathrm{mol}$ photons $\mathrm{m}^{-2} \mathrm{~s}^{-1}$ and an $\alpha$ of $0.003 \mathrm{nmol} \mathrm{O}_{2} \mathrm{~cm}^{-2} \mathrm{~s}^{-1} \mu \mathrm{mol}^{-1}$ photons $\mathrm{m}^{-2} \mathrm{~s}^{-1}$ (Fig. 4). The compensation point is approximately $2 \mu$ mol photons $\mathrm{m}^{-2} \mathrm{~s}^{-1}$. These estimations need to be considered as preliminary interpretations only, because of the limited quantity of data available.

Video observation of the under-ice oxygen and light measurements identified several unexpected influences on sea ice algal photosynthesis and growth. Some oxygen profiles indicated production levels far higher than was thought to be naturally possible. Video observations showed that these unusual profiles were usually associated with excessive oxygen bubble formation, which were almost entirely obtained in the afternoon after a cloud-free morning. These profiles were excluded from the above analysis as they were likely to contain oxygen contributed from the hanging community as well as the infiltration community and were thus likely to substantially overestimate production from the infiltration community. These profiles are thought to represent situations in which the oxygen production was greater than could be removed by diffusion and in consequence bubble formation resulted (Fig. 5). It is probable that the hanging algal strands also con-

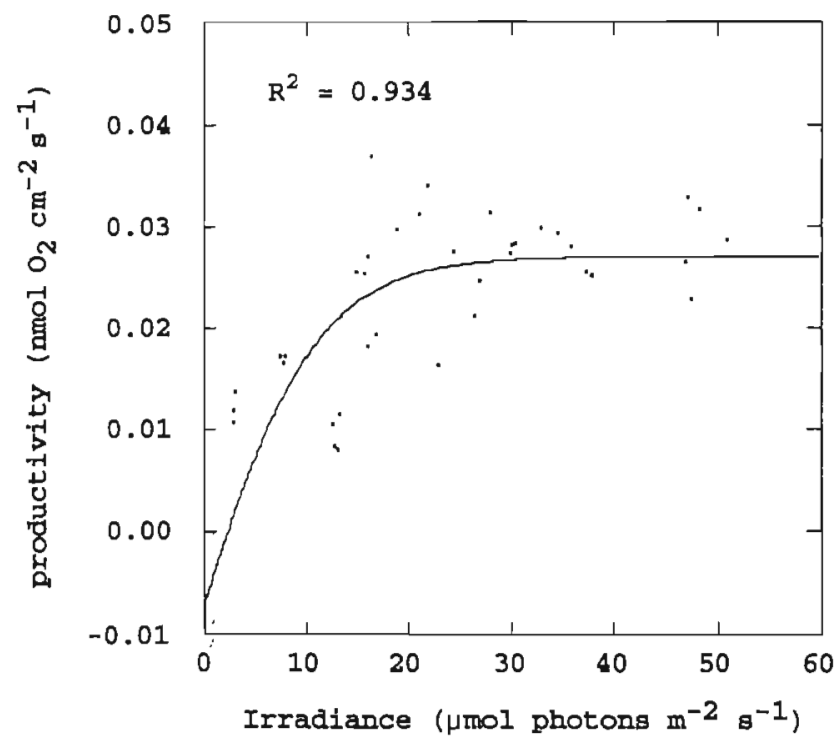

Fig. 4. Compilation of productivity ( $\mathrm{nmol} \mathrm{O}_{2} \mathrm{~cm}^{-2} \mathrm{~s}^{-1}$ ) versus irradiance ( $\mu \mathrm{mol}$ photons $\mathrm{m}^{-2} \mathrm{~s}^{-1}$ ) data from between 26 and 30 November. Data has been fitted to a hyperbolic tangent function to obtain $P_{\max }$ (maximun photosynthetic rate), $E_{k}$ (irradiance of the onset of saturation) and $\alpha$ (photosysthetic efficiency) (Jassby \& Platt 1976)

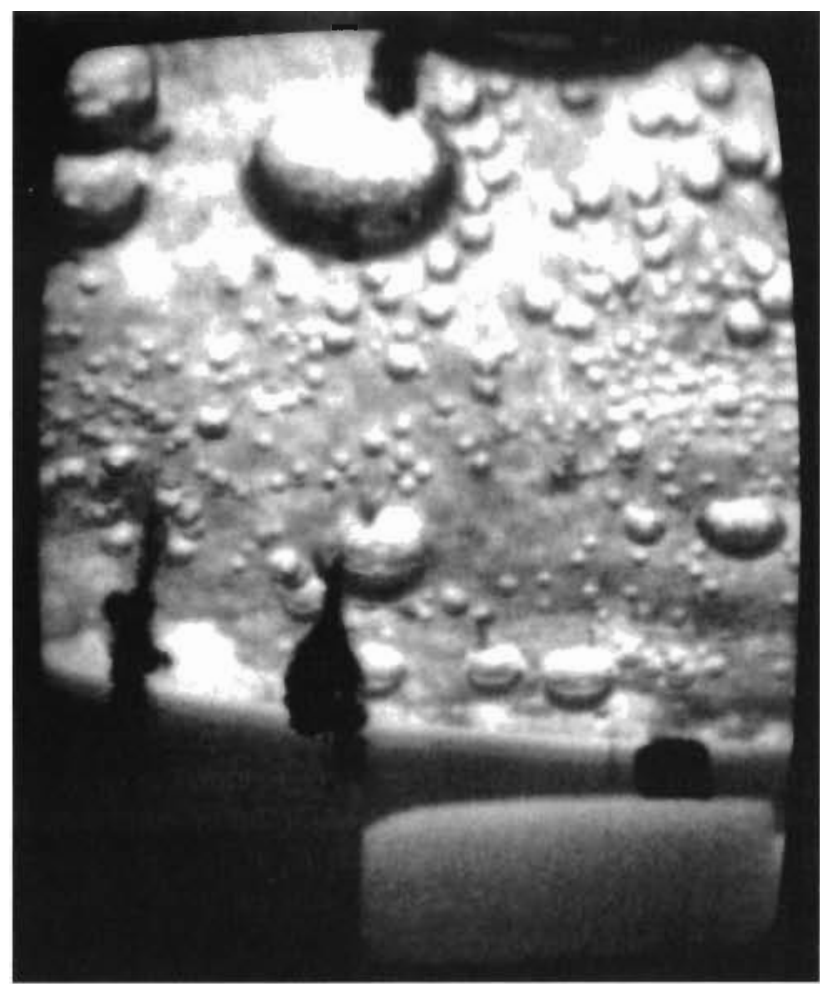

Fig. 5. Under ice photograph showing bubble accumulation and hanging strands of Berkelaya adeliense; the Nitzschia stellata community can be seen as areas of darker shading. Oxygen electrode can be seen approaching the ice surface. Scale: diameter of electrode housing is $15 \mathrm{~mm}$. Image was obtained by photographing the video monitor

tributed excess oxygen in the form of bubbles to the ice water interface as bubbles were seen forming on the strands. It must be remembered that, unlike benthic algal production, excess oxygen in the form of bubbles cannot float away to the surface but remains trapped by the overlying ice. $\mathrm{C}: \mathrm{chl}$ a ratios were not determined but if a value of 31 is adopted for algae from the bottom of fast ice in McMurdo Sound (Palmisano \& Sullivan 1983) then the algal biomass should have been increasing at a specific growth rate of at least $0.17 \mathrm{~d}^{-1}$. This should have seen the algal biomass nearly double over the $5 \mathrm{~d}$ on which measurements were taken. In contrast, the chl a biomass over this period actually declined, although the change was not statistically significant. Clearly, the estimated growth rate, which was based on commumity oxygen production, would provide only a minimum value as it did not include the amount of heterotrophic oxygen consumption. Video observation of the underside of the ice also revealed another important factor modifying productivity in this ecosystem. The amphipods Paramorea walkeri, sometimes with a density of greater than 100 ind. $\mathrm{m}^{-2}$, were regularly observed in association with the sea ice algal mat, al- 


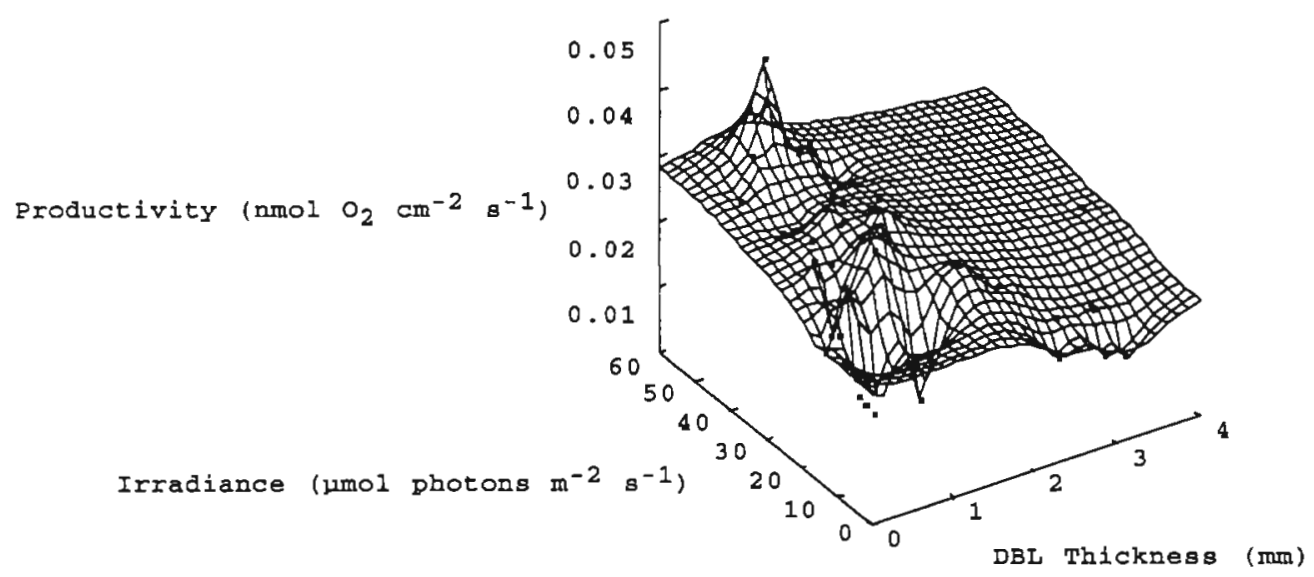

Fig. b. Productuvity versus irradiance versus curredi strength. DBL: diffusive boundary layer

though it was not actually possible to determine whether they were actively grazing

Under-ice tidal current velocities, which were estimated from the movement of suspended particles across the video screen, varied from less than $1 \mathrm{~cm} \mathrm{~s}^{-1}$ to over $20 \mathrm{~cm} \mathrm{~s}^{-1}$; the direction also varied by approximately $180^{\circ}$ over a day from SSW to NE. To examine the effects of current velocity on production the thickness of DBL, which responds directly to current strength, was used as a proxy as the velocities measured from the video screen were too imprecise. DBL thickness varied from 0.15 to $3.75 \mathrm{~mm}$ The relationship between current strength and production can be seen graphically in Fig. 6. A regression of productivity versus current strength (DBL thickness) showed a significant correlation (at $p<0.005$ ) and a squared multiple correlation of 0.482 . A stepwise multiple regression of photosynthesis versus irradiance and current strength (DBL thickness) gave highly significant $(\mathrm{p}<0.005)$ standardized coefficients of 0.793 for irradiance and 0.236 for current strength, indicating the lesser but still significant role of current strength in influencing rates of photosynthesis.

\section{DISCUSSION}

The photosynthetic rates of algae from the bottom of fast ice at Cape Evans in November 1997 were considerably higher than those measured at the same time of year and place in 1996 (McMinn et al. 1999b). In 1996 the ice was $1.7 \mathrm{~m}$ thick, it had a snow cover of $5 \mathrm{~cm}$ and average midday under-ice irradiances were less than $4 \mu \mathrm{mol}$ photons $\mathrm{m}^{-2} \mathrm{~s}^{-1}$. By comparison, in 1997 the ice was $0.9 \mathrm{~m}$ thick, there was no snow cover and average midday, clear sky under-ice irradiances were over $55 \mu \mathrm{mol}$ photons $\mathrm{m}^{-2} \mathrm{~s}^{-1}$. Maximum productivity in
1996 was only $0.0146 \mathrm{nmol} \mathrm{O} \mathrm{cm}^{-2} \mathrm{~s}^{-1}$ and the highest assimilation number only $0.05 \mathrm{mg} \mathrm{C} \mathrm{mg}^{-1} \mathrm{chl} \mathrm{a} \mathrm{h}^{-1}$ (McMinn et al. 1999b). This compares with a maximum productivity value in 1997 of $0.044 \mathrm{nmol} \mathrm{O} \mathrm{m}^{-2} \mathrm{~s}^{-1}$ and a maximum assimilation number of $2.01 \mathrm{mg} \mathrm{C} \mathrm{mg}^{-1}$ chl $a h^{-1}$. Both these data sets are consistent with results from similar ice environments. Low $P_{\max }$ values are characteristic of areas covered with both thick ice and snow and thus receive little light; $P_{\max }$ values in the range of 0.04 to $0.08 \mathrm{mg} \mathrm{C} \mathrm{mg}^{-1} \mathrm{chl} \mathrm{a} \mathrm{h}^{-1}$ are characteristic (Palmisano et al. 1985, 1987, Grossi et al. 1987 , McMinn \& Ashworth 1998, McMinn et al. 1999b). Fast ice areas receiving much higher quantities of light, such as at Cape Evans in 1997, have $P_{\max }$ values more than an order of magnitude greater than this $(0.74 \mathrm{mg}$ $\mathrm{C} \mathrm{mg}^{-1} \mathrm{chl} \mathrm{a} \mathrm{h}^{-1}$ ). In earlier studies by Grossi et al. (1987) and Smith et al. (1988) similar algal communities produced comparable values, approaching $2 \mathrm{mg} \mathrm{C}$ $\mathrm{mg}^{-1} \mathrm{chl} \mathrm{a} \mathrm{h}^{-1}$.

Sea ice algal biomass has a heterogeneous, patchy distribution on scales from meters to kilometers (Scott et al. 1994, Swadling et al. 1997) and at even less than a meter (Eicken et al. 1991). At Cape Evans the biomass, which was based on 5 replicate samples taken within $2 \mathrm{~m}$ of each other, was $17.1 \pm 1.9 \mathrm{mg} \mathrm{chl} \mathrm{a} \mathrm{m} \mathrm{m}^{-2}$ on 20 November but had decreased to $9.2 \pm 3.2 \mathrm{mg} \mathrm{chl} \mathrm{a}$ $\mathrm{m}^{-2}$ by 1 December. This degree of heterogeneity, while not particularly large, still suggests that many more productivity measurements need to be made to accurately calculate total sea ice production.

As sea ice melts, a layer of fresher water often develops beneath the ice (Cota \& Horne 1989, McMinn \& Hodgson 1993) and, similarly, as sea ice forms, brine is excluded from the ice, creating increased salinity levels beneath the ice. The development of these gradients has the potential to significantly influence the transport of solutes across the ice water interface. At 
Cape Evans there was no detectable change in ice thickness over the experimental period. Furthermore, there was no significant change in the temperature of the water beneath the ice, which remained between -1.8 and $-1.7^{\circ} \mathrm{C}$. These factors suggest that ice growth or melt during this time was not significant and that diffusive rather than convective molecular transport was the principal method of transporting oxygen. This is further supported by the similarity of sea ice algal production measurements using the oxygen electrode method compared with conventional $\mathrm{C}^{14}$ techniques (Grossi et al. 1987, Palmisano et al. 1987). However, the development of salinity gradients early in the season, during rapid ice formation, or late in the season, during ice melt, would constrain the use of this method at these times.

The taxonomic composition of the under-ice algal community in 1996 (McMinn 1998) and 1997 was similar, although the relative abundance of the major species varied considerably. The large difference in photosynthetic parameters between the 2 years indicates the algal community to be capable of photoacclimatisation. The ability of sea ice algal communities to photoacclimate to both increasing and decreasing irradiances over the course of several days was demonstrated by Lizotte \& Sullivan (1991). This was achieved largely through varying the quantity of chlorophyll per cell. The relatively low under-ice chlorophyll biomass recorded in 1997 may therefore reflect, at least in part, reduced chlorophyll per cell rather than fewer cells. Similarly, the apparent decline in chlorophyll biomass between 26 and 30 November may reflect photoacclimatisation rather than declining cell numbers.

The importance of tidal currents in regulating the productivity of sea ice algal mats was first recognized in the Arctic (Cota et al. 1987, Cota \& Horne 1989), where increasing tidal currents disrupted a well-stratified water column resulting in the increased transfer of nutrients across the pycnocline (Cota \& Horne 1989). During the Cape Evans measurements, however, the water column was mostly well mixed and so this type of control on productivity by large-scale nutrient limitation would be less well developed. Instead, tidal currents are thought to influence production by effecting the thickness of the DBL.

Increasing the current velocity over benthic macro algal and cyanobacterial communities leads to an increased net photosynthetic rate (Westlake 1967, Dodds 1989, Glud et al. 1992, Kuhl et al. 1996). The reduction in the DBL thickness caused by increasing current velocity leads to a more efficient transport of nutrients into the mat and a more efficient transport of oxygen away from the mat. As high levels of $\mathrm{O}_{2}$ can be toxic and inhibitory to photosynthesis (Raven \& Beardall 1981), the more efficient removal of $\mathrm{O}_{2}$ could lead to increased photosynthetic rates (Dodds 1989, Glud et al. 1992). Both Kuhl et al. (1996) and Dodds (1989) reported a doubling of net photosynthesis in benthic cyanobacterial communities when current velocities were increased from 0 to $10 \mathrm{~cm} \mathrm{~s}^{-1}$. There is a wellestablished relationship between increasing current strength and decreasing DBL thickness (Jørgensen \& Des Marais 1990). We were not able to measure current strength directly and so are using the DBL thickness as a current strength proxy. A stepwise multiple regression analysis of the under-ice production data reported here (Fig. 6) also reveals a correlation between current strength (DBL thickness) and productivity. An approximate doubling of production between low current velocities, i.e. less than $5 \mathrm{~cm}^{-1}$ with a thick DBL and higher current velocities with a thinner DBL, is also reported. Increased current velocities affect not only those cells at the ice water interface but the entire community by decreasing diffusional barriers at the ice water interface. This leads to a greater nutrient flux to all cells and thus a greater export of oxygen. It is also likely to effect community respiration levels well above the ice water interface (Kuhl et al. 1996).

It has now been shown that inserting microelectrodes into DBLs effects both the thickness of the boundary layer and the distribution of oxygen within the underlying sediment or algal mat (Glud et al. 1994, Lorenzen et al. 1995). Reduction in the thickness of the DBL can lead to an overestimate of production by up to $59 \%$ (Glud et al. 1994), although overestimates of less than $10 \%$ are more common (Glud et al. 1994, Lorenzen et al. 1995). Lorenzen et al. (1995) also found that natural variation in space and time might be a more important source of error for the estimation of net photosynthesis than microelectrode effects. Using Fick's 1-dimensional diffusional model to calculate oxygen flux can also lead to substantial errors. Jørgensen \& Des Marais (1990) found that the estimate of production in a hypersaline cyanobacterial mat was $49 \%$ less using the 1-dimensional model than if a 3-dimensional approach was taken. In an even more extreme case, it was found that the oxygen flux across the sediment water interface in deep-sea sediments was underestimated by a factor of up to $2.5 \times$ if the 1-dimensional rather than a 3-dimensional approach was used (Gundersen \& Jørgensen 1990). However, Lorenzen et al. (1995) and Glud et al. (1994) all argue that if the oxygen profiles through the $\mathrm{DBL}$ are linear, as they are here, there is minimal horizontal transport of oxygen and the basic 1-dimensional calculation of fluxes is valid.

Wherever algae grow on the bottom of the sea ice, they are going to be susceptible to the effects of currents. This will include most of the fast ice algal biomass and a considerable proportion of that occurring in the pack ice. Arrigo et al. (1997) dismissed the contribution 
of bottom communities to total pack ice productivity as unimportant, but our unpublished observations in the pack ice off eastern Antarctica suggest that in this region at least bottom communities are dominant. These communities are usually influenced by the strong ocean currents associated with the West Wind Drift and consequently are likely to experience elevated production levels. Naturally, surface ice communities will be unaffected by current strength. The implications of these observations on the role of under-ice currents extends to all measurements of sea ice algal productivity. Sea ice algal incubations in sealed containers, even those measured in situ, will not have included a measure of the effects of current velocity on production and are therefore likely to underestimate net production. Clearly, more attention will need to be given to productivity measurements that do not disturb the sea ice habitat.

In most benthic environments the toxic effects of excessive $\mathrm{O}_{2}$ build-up are reduced when bubbles form and then float off. The bottom of the sea ice provides a probable unique exception to this situation as $\mathrm{O}_{2}$ bubbles, being unable to escape, are trapped and so accumulate. At times at Cape Evans more than $80 \%$ of the under-ice area was covered with bubbles. This occurred on cloud-free days when midday under ice irradiances exceeded $55 \mu \mathrm{mol}$ photons $\mathrm{m}^{-2} \mathrm{~s}^{-1}$. The bubbles dissipated when either current velocities increased and/or irradiances were reduced by either cloud cover or approaching nightfall. The effects of bubble formation on the sea ice algal mats are uncertain but it is likely to lead to a reduction in photosynthesis and growth and possibly increased mortality (Raven \& Beardall 1981).

Amphipods, sometimes with a density of $>100$ ind. $\mathrm{m}^{-2}$, were regularly observed on the sea ice algal mat. Amphipods beneath Arctic sea ice are able to consume between 1.1 and $2.6 \%$ of the algal biomass per day (Werner 1997). While the consumption of algae by amphipods at Cape Evans was not quantified, they also possibly contributed to the apparent decline in algal biomass over the $5 \mathrm{~d}$ of study.

Accumulation of sea ice algal biomass is not just a function of how much light it has received. We have shown here that under-ice current velocity and possibly oxygen build-up and grazing by amphipods and krill (Marshall 1988, Stretch et al. 1988, Daly 1990) influence biomass accumulation and photosynthetic rates. The amount of light received by the algae in this study was higher than that reported in most previous studies but cannot be considered rare. In spite of the high irradiance, loss mechanisms such as grazing and possibly oxygen toxicity were able to prevent the buildup of additional biomass.

Although there are clearly some constraints in the use and interpretation of sea ice algal productivity esti- mates using the in situ micro oxygen electrode method, it also offers some distinct advantages. Most importantly, the full range of natural processes that have the potential to effect productivity such as nutrient limitation, current strength and grazing are unaffected. Furthermore, the sea ice algal communities are not handled at all and the illumination to which the algal mats are exposed is completely natural. These strengths should enable new approaches to sea ice algal mat research to be developed.

Acknowledgements. We acknowledge the financial assistance of an ARC grant and an ASAC grant. We also acknowledge the logistical support of Antarctica New Zealand and in particular the help of Tim Haskell (Event K131) of Industrial Research Ltd, Wellington, New Lealand. Harvey Marchant of the Australian Antarctic Division is thanked for reviewing an early draft of this manuscript.

\section{LITERATURE CITED}

Arrigo KR, Worthen DL, Lizotte MP, Dixon P, Dieckmann G (1997) Primary production in Antarctic sea ice. Science 276: $394-397$

Broecker WS, Peng TH (1974) Gas exchange rates between air and sea. Tellus 26: 21-35

Buckley RG, Trodahl HJ (1990) Diffusion of light in Antarctic sea ice. Mater Research Soc Symp Proc 195: 103-107

Cota FG, Horne EPW (1989) Physical control of Arctic ice algal production. Mar Ecol Prog Ser 52:111-121

Cota FG, Smith REH (1991) Ecology of bottom ice algae: III. Comparative physiology. J Mar Syst 2:297-315

Cota FG, Prinsenberg SJ, Bennett EB, Loder JW, Lewis MR, Anning JL, Watson NH, Harris LR (1987) Nutrient fluxes during extended blooms of arctic ice algae. J Geophys Res 92:1951-1962

Daly KL (1990) Over wintering development, growth and feeding of larval Euphausia superba in the Antarctic marginal ice zone. Limnol Oceanogr 35:1564-1576

Dodds WK (1989) Photosynthesis of two morphologies of Nostoc parmelloides (Cyanobacteria) as related to current velocities and diffusion patterns. J Phycol 25: 258-262

Dodds WK, Biggs BJF, Lowe RL (1999) Photosynthesis-irradiance patterns in benthic microalgae: variations as a function of assemblage thickness and community structure. J Phycol 35:42-53

Dwight HB (1961) Tables of integrals and other mathematical data, 4th edn. Macmillian, New York

Eicken H, Lange MA, Dieckmann DS (1991) Spatial variability of sea ice properties in the northwestern Weddell Sea. J Geophys Res 96:10603-10615

Glud RN, Ramsing NB, Revsbech NP (1992) Photosynthesis and photosynthesis-coupled respiration in natural biofilms quantified with oxygen microsensors. J Phycol 28: 51-60

Glud RN, Gundersen JK, Revsbech NP, Jørgensen BB (1994) Effects on the diffusive boundary layer imposed by microelectrodes. Limnol Oceanogr 39:462-467

Grossi SM, Kottmeier ST, Moe RL, Taylor GT, Sullivan CW (1987) Sea ice microbial communities. VI. Growth and primary production in bottom ice under graded snow cover. Mar Ecol Prog Ser 35:153-164

Gunderson JK, Jørgensen BB (1990) Microstructure of diffu- 
sive boundary layers and the oxygen uptake of the sea floor. Nature 345:604-607

Irwin BD (1990) Primary production of ice algae on a seasonally ice-covered continental shelf. Polar Biol 10:247-254

Jassby AT, Platt T (1976) Mathematical formulation of the relationship between photosynthesis and light for phytoplankton. Limnol Oceanogr 21:540-547

Jargensen BB, Des Marais DJ (1990) The diffusive boundary layer of sediments: oxygen microgradients over a microbial mat. Limnol Oceanogr 35:1343-1355

Jørgensen BB, Revsbech NP (1985) Diffusive boundary layers and the oxygen uptake of sediments and detritus. Limnol Oceanogr 30:111-122

Kuhl M, Lassen C, Jørgensen BB (1994) Light penetration and light intensity in sandy marine sediments measured with irradiance and scalar irradiance fibre-optic microprobes. Mar Ecol Prog Ser 105:139-148

Kuhl M, Glud RN, Ploug H, Ramsing NB (1996) Microenvironmental control of photosynthesis and photosynthesiscoupled respiration in an epilithic cyanobacterial biofilm. J Phycol 32:799-812

Legendre L, Ackley SF, Dieckmann GS, Gulliksen B, Horner R, Hoshiai T, Melnikov IA, Reeburgh WS, Spindler M, Sullivan CW (1992) Ecology of sea ice biota. 2. Global significance. Polar Biol 12:429-444

Lizotte MP, Sullivan CW (1991) Rates of photoadaption in sea ice diatoms from McMurdo Sound, Antarctica. J Phycol $27: 367-373$

Lizotte MP, Sullivan CW (1992) Biochemical composition and photosynthate distribution in sea ice microalgae of McMurdo Sound, Antarctica: evidence for nutrient stress during the spring bloom. Antarct Sci 4:23-30

Lorenzen J, Glud RN, Revsbech NP (1995) Impact of microsensor-caused changes in diffusive boundary layer thickness on $\mathrm{O}_{2}$ profiles and photosynthetic rates in benthic communities of microorganisms. Mar Ecol Prog Ser 119: $237-241$

Maestrini SY, Rochet M, Legendre L, Demers S (1986) Nutrient limitation of the bottom-ice microalgal biomass (southeastern Hudson Bay, Canadian Arctic). Limnol Oceanogr 31:969-982

Marshall HP (1988) The overwintering strategy of Antarctic krill under the pack ice of the Weddell Sea. Polar Biol 9:129-135

Maykut GA (1985) The ice environment. In: Horner RA (ed) Sea ice biota. CRC Press, Boca Raton, p 21-82

McConville MJ, Wetherbee R (1983) The bottom-ice microalgal community from annual ice in the inshore waters of East Antarctica. J Phycol 19:431-439

McMinn A (1998) Species succession in fast ice algal communities; a response to UV-B radiation? Korean J Polar Res 8:47-52

McMinn A, Ashworth C (1998) The use of oxygen microelectrodes to determine the net production by an Antarctic sea ice algal community. Antarct Sci 10:39-44

McMinn A, Hodgson D (1993) Seasonal phytoplankton succession in Ellis Fjord, eastern Antarctica. J Plankton Res 15:925-938

McMinn A, Trull T, Skerratt J, Lizotte M (1999a) Nutrient stress gradient in the bottom $5 \mathrm{~cm}$ of fast ice, McMurdo Sound, Antarctica. Polar Biol 21:220-227

McMinn A, Ashworth C, Ryan K (1999b) Growth and productivity of Antarctic sea ice algae under PAR and UV irradiances. Bot Mar 42:401-407

Palmisano AC, Sullivan CW (1983) Sea ice microbial communities (SIMCO). 1. Distribution, abundance, and primary production of microalgae in McMurdo Sound, Antarctica in 1980. Polar Biol 2:171-177

Palmisano AC, SooHoo JB, Sullivan CW (1985) Photosynthesis-irradiance relationships in sea ice microalgae from McMurdo Sound, Antarctica. J Phycol 21:341-346

Palmisano AC, Beeler SooHoo J, Sullivan CW (1987) Effects of four environmental variables on photosynthesis-irradiance relationships in Antarctic sea ice microalgae. Mar Biol 94:299-306

Palmisano A, Lizotte MP, Smith GA, Nichols PD, White DC, Sullivan CW (1988) Changes in photosynthetic carbon assimilation in Antarctic sea-ice diatoms during spring bloom: variation in synthesis of lipid classes. J Exp Mar Biol Ecol 116:1-13

Platt TC, Gallegos L, Harrison WG (1980) Photoinhibition of photosynthesis in natural assemblages of marine phytoplankton. J Mar Res 38:687-701

Raven JA, Beardall J (1981) Respiration and photorespiration. In: Platt T (ed) Physiologocal bases of phytoplankton ecology. Canadian Bulletin of Fisheries and Aquatic Science, Ottawa, p 55-82

Revsbech NP, Jørgensen BB (1986) Microelectrodes: their use in microbial ecology. Adv Microb Ecol 9:293-352

Ryan KG, Beaglehole D (1994) Ultraviolet radiation and bottom-ice algae: laboratory and field studies from McMurdo Sound, Antarctica. In: Weiler CS, Penhale PA (eds) Ultraviolet radiation in Antarctica: measurement and biological effects. Antarctic Research Series, Vol 62. American Geophysical Union, Washington, p 229-242

Satoh H, Watanabe K (1988) Primary productivity in the fast ice area near Syowa station, Antarctica, during spring and summer 1983/84. J Oceanogr Soc Jpn 44:287-292

Scott P, McMinn A, Hosie G (1994) Physical parameters influencing diatom community structure in eastern Antarctic sea ice. Polar Biol 14:507-517

Smith REH, Anning J, Clement P, Cota G (1988) Abundance and production of ice algae in Resolute Passage, Canadian Arctic. Mar Ecol Prog Ser 48:251-263

Smith, REH, Clement P, Head EJ (1989) Biosynthesis and photosynthetic allocation patterns of Arctic ice algae. Limnol Oceanogr 34:591-605

SooHoo JB, Palmisano AC, Lizotte MP, Kottmeier ST, SooHoo SL, Sullivan CW (1987) Spectral light absorption and quantum yield of photosynthesis in sea ice microalgae and a bloom of Phaeocystis pouchettii from McMurdo Sound, Antarctica. Mar Ecol Prog Ser 39:175-189

Steemann Nielsen E (1952) Use of radioactive carbon (C14) for measuring organic production in the sea. J Cons Int Explor Mer 18:117-140

Stretch JJ, Hamner PP, Hamner WM, Michel WC, Cook J, Sullivan CW (1988) Foraging behaviour of antarctic krill (Euphausia superba) on sea ice microalgae. Mar Biol 144: $131-139$

Strickland JDH, Parsons TR (1972) A practical handbook of seawater analysis, 2nd edn. Bull Fish Res Board Can, 167

Swadling KM, Gibson JAE, Ritz DA, Nichols PD (1997) Horizontal patchiness in sympagic organisms of the Antarctic fast ice. Antarct Sci 9:399-406

Watanabe K (1988) Sub-ice microalgal strands in the Antarctic coastal fast ice near Syowa Station. Jpn J Phycol $37: 221-229$

Weiss RF (1970) The solubility of nitrogen, oxygen and argon in water and seawater. Deep-Sea Res 17:721-735

Werner I (1997) Grazing of Arctic under ice amphipods on sea ice algae. Mar Ecol Prog Ser 160:93-99

Westlake DF (1967) Some effects of low velocity currents on the metabolism of aquatic macrophytes. J Exp Bot 18: $187-205$ 